\title{
Speciation of troglobites: studies in the San Antonio cave (Oaxaca, Mexico)
}

\author{
Horst Wilkens, Peter Junge and Thomas G. Langecker*
}

\begin{abstract}
SUMMARY
The phylogenetically young species community of San Antonio Cave (Oaxaca, Mexico) exemplifies the hypothesis that speciation of troglobites can occur in close contact with epigean predecessors. In a subterranean creek which continues outside with a rich epigean fauna, four troglobitic aquatic crustacean and one fish species (Rhamdia reddelli, Pimelodidae) were studied. Today not a single surface specimen can be found in the cave waters although several epigean species are troglophilic and/or are the ancestors of cave forms in other parts of Mexico. The absence of epigean invaders is attributed to the presence of specimens of some of the more aggressive and carnivorous cave species close to the cave entrance.

Contrary to this it can be presumed that at the beginning of the troglobitic evolution the cave ancestral epigean forms were regularly invading the cave. It is assumed that photonegative behavior played a role for the initial colonization of the cave but it is not of significance as a separating mechanism for the speciation process.
\end{abstract}

\section{INTRODUCTION}

The speciation of cave animals is still today a matter of controversy. Concerning the initial colonization of the cave biotope, the "refugium model" has been widely accepted in the past (Vandel, 1964). It explains the origin of cave species as being derived from epigean forms which have taken refuge in the cave due to environmental changes. Today the view of an "active colonization" is gaining more and more acceptance (Rouch \& Danielopol, 1987). This model implies that troglophilic epigean species actively invade the subterranean biotope while still existing at the surface.

It is generally accepted that the speciation process following an invasion requires the final interruption of the gene flow between the

* Zoologisches Institut und Zoologisches Museum Universität Hamburg, MartinLuther-King-Platz 3, 2000 Hamburg 13 
newly founded cave population and the epigean ancestor. For this, various mechanisms are considered responsible. Above all the extinction or geographic separation of the ancestral form is thought to be most important (Barr \& Holsinger, 1985). Contrary to this, Howarth $(1981,1987)$ proposed that non-relictual Hawaiian troglobites may evolve by a process of an adaptive shift from species that are frequent accidentals in caves. Similarly it has been found in cave living populations of the fish Astyanax fasciatus that speciation may even occur in a narrowly sympatric contact with the epigean form (Wilkens \& Hüppop, 1986).

The "San Antonio Cave" (Cueva del Nacimiento del Rio San Antonio) which is located in the Acatlán region of Oaxaca (Mexico) (Reddell, 1981) is an excellent model to study speciation processes in cave animals. This cave is characterized by a continuous aquatic connection between the subterranean creek and the surface river which emerges at the cave entrance. Furthermore the cave portion is colonized by several aquatic troglobitic species. These species all show intermediate eye and pigment reduction (Wilkens, 1986) and thus are supposed to be recent invaders with still existing epigean ancestors. One of these is the catfish Rhamdia reddelli Miller, 1984 (Pimelodidae), which can be derived from the neotropical genus Rhamdia which is widely distributed in epigean waters in Southern Mexico and Belize (Miller, 1966, 1984; Greenfield et al., 1983; Robertson, 1983 a, b; Mosier, 1984).

\section{MATERIAL AND METHODS}

The field studies in the San Antonio Cave were performed in February 1988. Six cave fish (standard length $75 \mathrm{~mm}$ to $130 \mathrm{~mm}$ ) had been brought alive to our Hamburg laboratory. Their phototactic behavior was investigated and compared with that of 4 specimens of their epigean predecessor Rhamdia laticauda (standard length 130 $\mathrm{mm}$ to $155 \mathrm{~mm}$ ) which were captured in Mexico and with six specimens of the related surface fish Rhamdia guatemalensis (standard length $70 \mathrm{~mm}$ to $110 \mathrm{~mm}$ ) which were derived from offspring of R. guatemalensis from Yucatan (Mexico). All fish were individually tested for their choice-preference behavior to white light of different intensities. 
The fish were placed into experimental tanks (25 l) subdivided into a darkened and a lighted compartment. After seven days of acclimation under bright light (620 Lux at the bottom of the lighted half) in a light-dark cycle of $12: 12 \mathrm{~h}$, the time the fish spent in the lighted compartment was recorded during a time period of 5 minutes three times the day over 5 days thus giving a total of 30 experiments. Subsequently, the same experiments were performed using lower light intensities (50 Lux and 3 Lux at the bottom of the lighted half).

The authors are greatful to the "Johanna und Fritz Buch Gedächtnisstiftung" and the "Hanseatische Universitätsstiftung" who financially supported these studies. R. Stawikowski (Gelsenkirchen) kindly determined the cichlid species.

\section{TOPOGRAPHIC AND PHYSIOGRAPHIC DESCRIPTION}

The San Antonio Cave consists of an accessible slightly sloping main branch with a length of about $500 \mathrm{~m}$. A partially explored upper level pássage is found some $300 \mathrm{~m}$ from the main cave entrance. The cave creek begins at the end of the main branch forming a little cascade between boulders of breakdown. The breakdown prevents any further human penetration into the main branch of the cave (Fig. 1). From its emergence the creek flows for a distance of about $320 \mathrm{~m}$, and then disappears into a lower passage and is invisible. With the exception of a spacially limited breakdown area, the so-called basin, the creek remains inaccessible until it discharges from the front of the cave.

The creek flows between steep banks of loamy soil. During the dry season the creek is about $0,5 \mathrm{~m}$ wide, $10 \mathrm{~cm}$ deep and shows rather rapid water flow. Only two sections have less current. One of these (pool 1) is located at the base of the emergence cascade, the second (pool 2) is formed at about $130 \mathrm{~m}$ downstream. Absolutely stagnant, isolated pools are situated in the upper level side branch of the cave system. Water temperature is $22^{\circ} \mathrm{C}$.

The original cave entrance is blocked by breakdown, and water can pass only through narrow crevices. Due to this the drainage is retarded. Rainfalls may cause a quick rise of the water level in the cave for a short time. In February 1988 the basin was totally flooded for few days. During the rainy season, however, the water level rises 


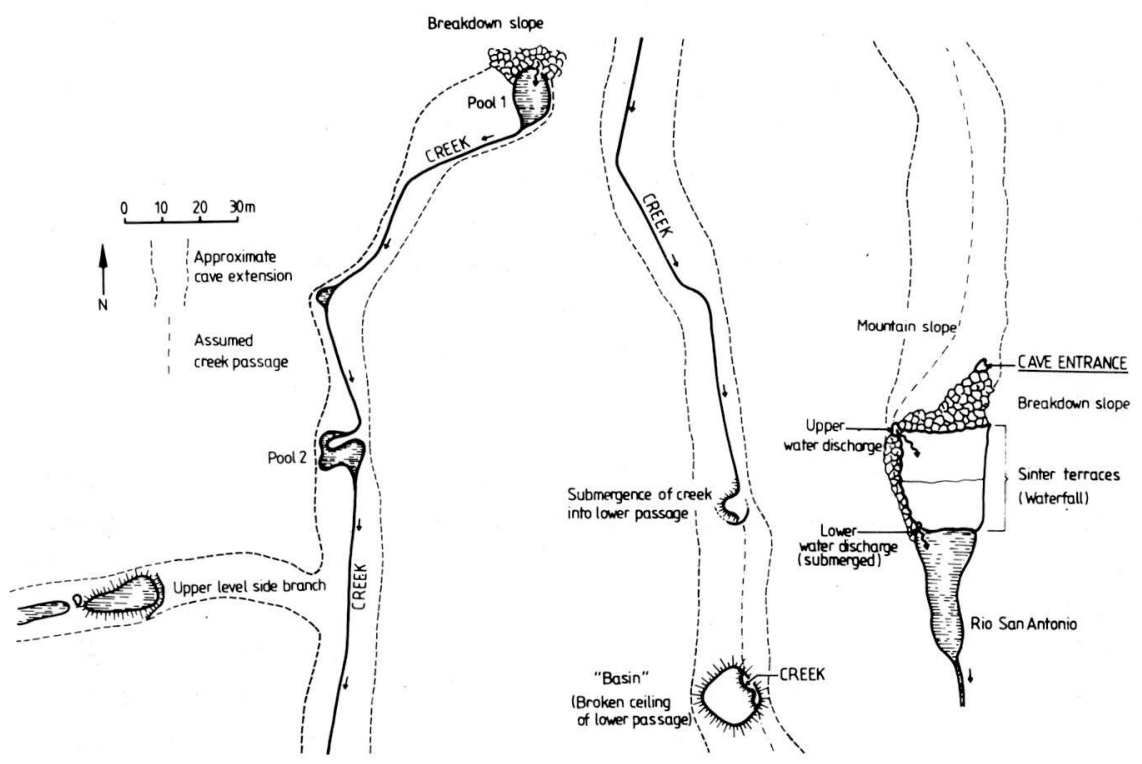

Fig. 1 - The explored section of the Cueva del Nacimiento del Rio San Antonio

even higher. At least in parts, the water body totally fills the cave up to the ceiling. In addition to the discharge within the pool in front of the cave, water then starts streaming out of a second opening in the breakdown slope about $5 \mathrm{~m}$ above. The increased water flow causes a considerably sized waterfall to develop. This waterfall has over the years eroded the initial section of the epigean Rio San Antonio for some distance, forming the above mentioned pool.

\section{SPECIES SPECTRUM AND DISTRIBUTION OF THE FISH AND CRUSTACEAN FAUNA}

\section{Cave species}

- Procambarus oaxacae reddelli Hobbs, 1973 a (Cambaridae, Decapoda)

$P$. oaxacae reddelli has lost the dark body pigmentation. The pigmentation does not regenerate under day light conditions when the crayfish are kept in the laboratory. The complex eye has regressed to a tiny dark spot located on the tip of the eye stalk. It 
consists of a reduced number of intact ommatidia (Wilkens, 1986). The crayfish therefore cannot merely perceive light but are still able to visualize approaching figures.

$P$. oaxacae reddelli is the most conspicuous among the crustacean cave species of the San Antonio Cave. It can be found throughout the subterranean creek system, but prefers passages with less current.

- Macrobrachium villalobosi Hobbs, 1973 b (Palaemonidae, Natantia)

The shrimp $M$. villalobosi has also totally lost its dark body pigmentation. No darkening can be observed when kept under day light conditions for several months. The compound eye is reduced to a tiny dark pigment spot on the tip of the eye stalk. Several specimens were observed to carry large eggs beneath the pleon. They number about 15 and have a diameter of $1.0 \mathrm{~mm}$. The development takes a time of at least 3 months after which a postlarva of about 2 $\mathrm{mm}$ in length hatches.

In the cave $M$. villalobosi is much rarer than $P$. oaxacae reddelli. It occurs in stagnant pools or portions of the creek with very slow water movement. Specimens prefer deeper water bodies as they are found in the upper level passage or in the pool beneath the water fall (Fig. 1).

\section{- Potamalpheops stygicola Hobbs, 1973 b (Alpheidae, Decapoda)}

$P$. stygicola shows no body coloration when caught in the cave. In the laboratory, however, stellate erythrophores are developed after some time. This is probably due to the food containing carotinoids. The outer appearance of the eye coincides with that of M. villalobosi.

In the cave $P$. stygicola did not occur in the creek but in extremely shallow nearly or completely isolated puddles. Here it was found associated with Antromysis reddelli Bowman (Mysidacea).

- Rhamdia reddelli Miller, 1984 (Pimelodidae, Pisces)

The specimens of the catfish $R$. reddelli caught in their natural biotope show a light body coloration. When kept in the laboratory they will become darkish grey. There is no considerable interindivi- 


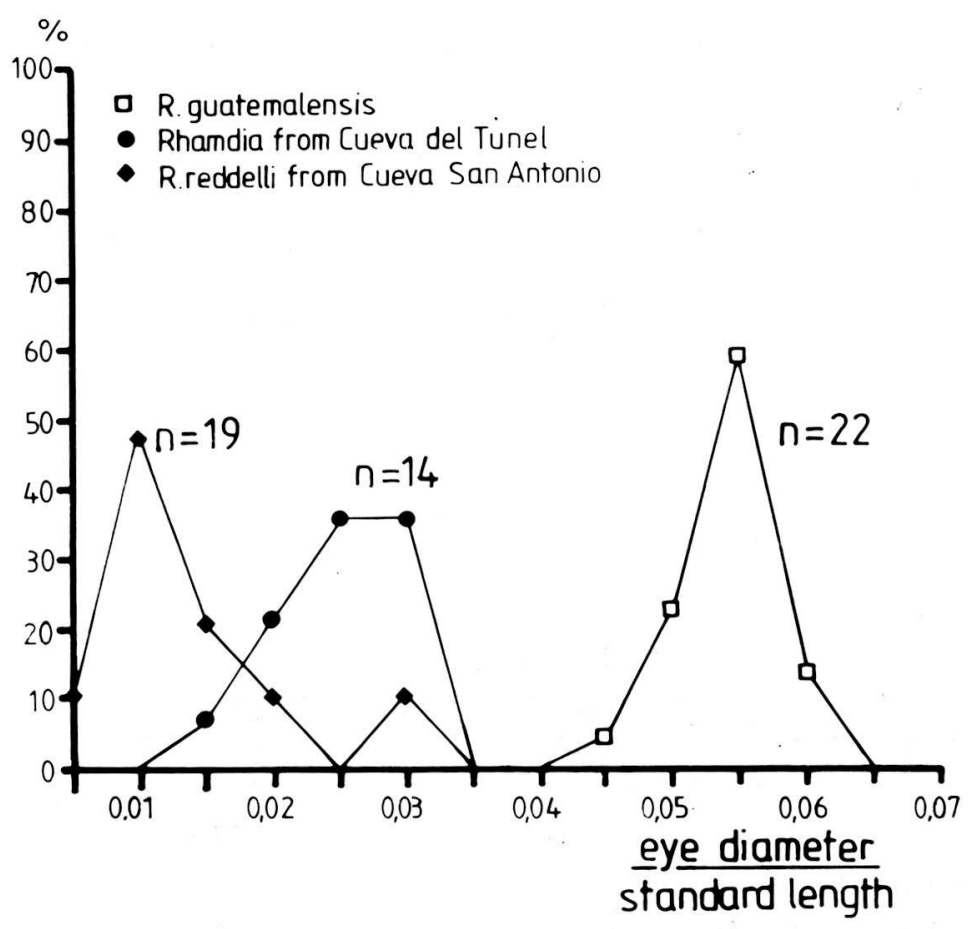

Fig. 2 - Comparison of eye size in the epigean Rhamdia guatemalensis, the cave $R$. reddelli, and the undescribed Cueva del Túnel cave population (Samples from 1982, 1986, and 1988)

dual variability of pigmentation. The eyes are reduced and sunk beneath the body surface. They show a bimodal size distribution. The mean eye size is lower than that of another cave-dwelling form of Rhamdia (Fig. 2).

The body size of $R$. reddelli ranges from about 6.0 to $15.0 \mathrm{~cm}$ (Fig. 3). All specimens were in a good nutritional state and did not show signs of malnutrition, as could be observed in the population of cave-inhabiting Rhamdia from the Cueva del Túnel in 1988 (Fig. 4).

In principle $R$. reddelli is distributed throughout the creek of the San Antonio Cave. However, the catfish are usually found in larger numbers in the sections with less rapid current (pool 1 and 2) and in the so-called "basin" (Fig. 1). During the dry season the "basin" only contains water after an occasional rainfall. At such times it is 


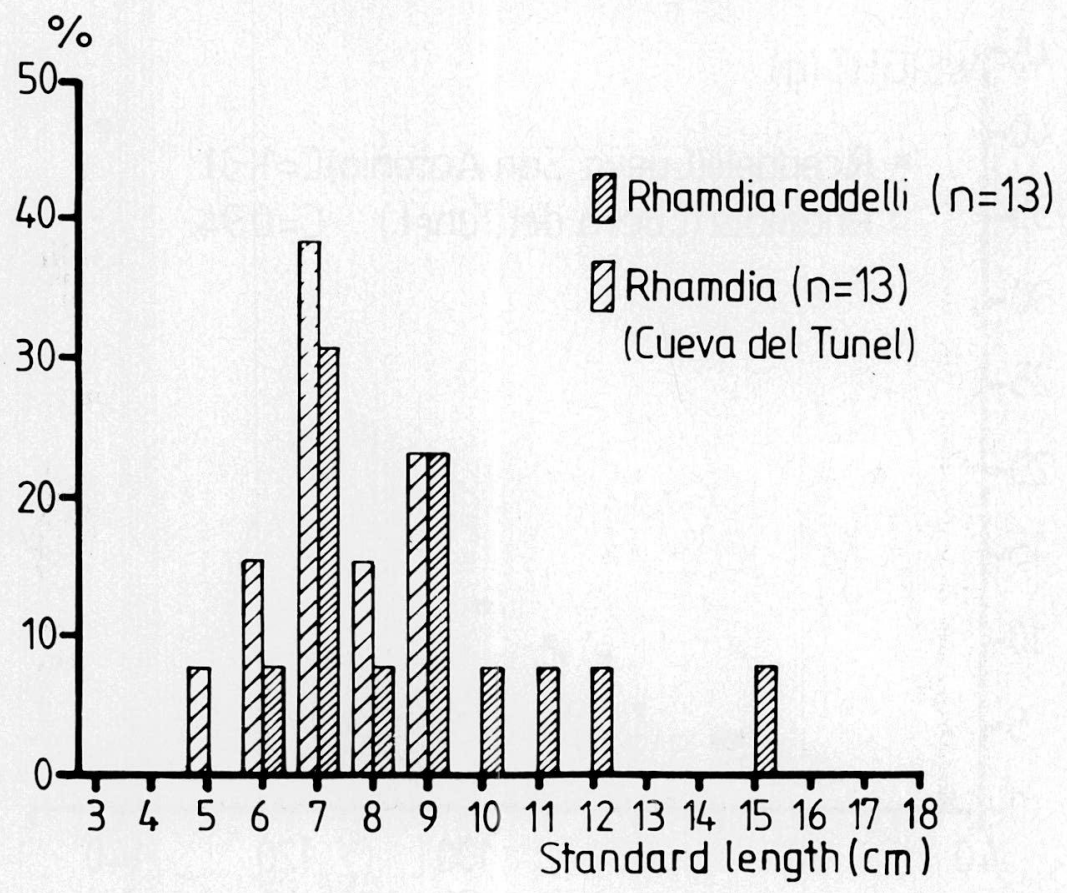

Fig. 3 - Distribution of body size in specimens of $R$. reddelli and the undescribed Cueva del Túnel cave population (Samples from February 1988)

immediately invaded by specimens of $R$. reddelli. They are probably attracted by organic matter which is washed into it from the banks of the subterranean creek and finally sinks to the bottom in this rather slowly streaming section. Presumably these specimens normally stay in the narrow passages between the "basin" and the cave entrance (Fig. 1).

\section{Epigean species}

In the subterranean creek no epigean invaders were found. The epigean creek adjacent to the cave entrance, however, is inhabited by a rich fish and crustacean fauna. The most common fish species is Astyanax fasciatus (Cuvier, 1819) (Characidae) followed by several species of Cichlidae (Thorichthys ellioti Meek, 1904, Cichlasoma fenestratum (Günther, 1860), and an introduced African Oreochromis 


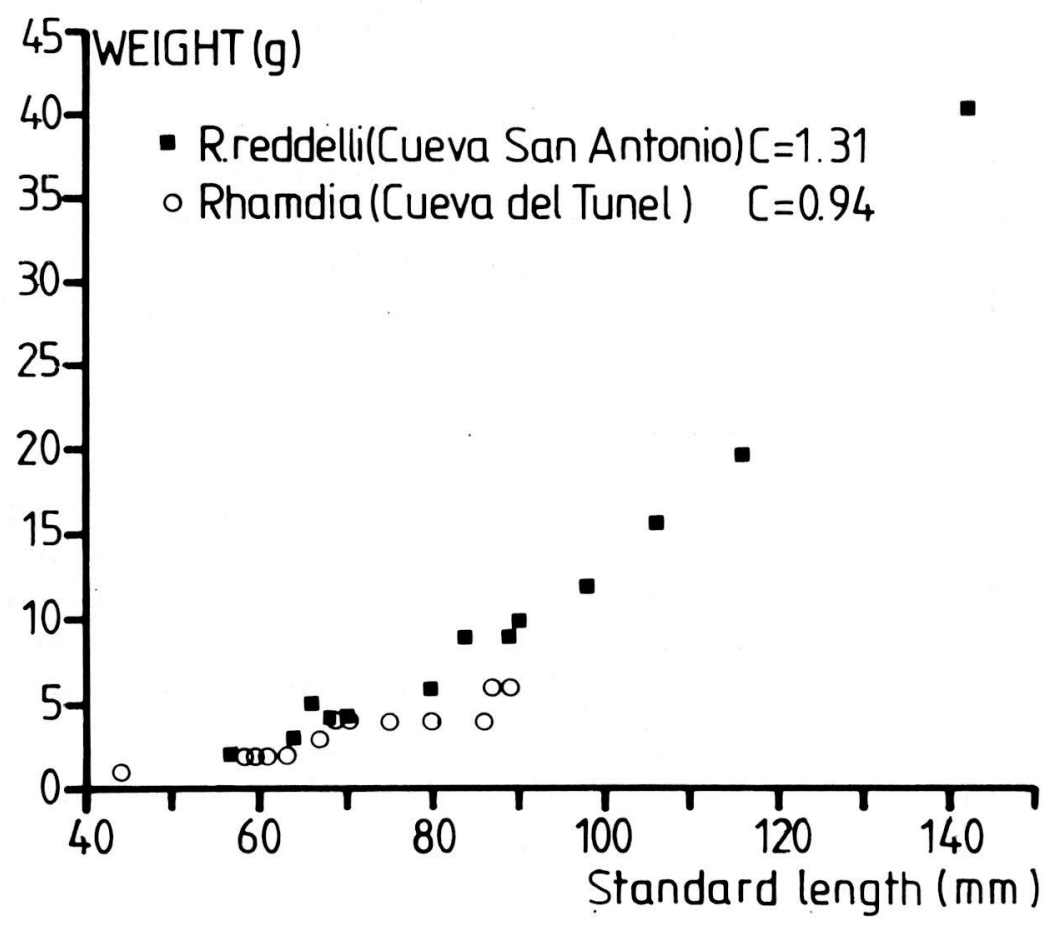

Fig. 4 - Body size and weight of specimens of $R$. reddelli from the San Antonio Cave and of the undescribed Cueva del Túnel cave population (Measurements two days after sampling)

spec.) which all closely approach the submerged area of the lower water discharge of the cave creek. Furthermore Xiphophorus helleri Heckel, 1848, Heterandria bimaculata (Heckel, 1848), and Belonesox belizanus Kner, 1860 (Poeciliidae) occur. At night the active species spectrum changes. Between rocky fissures the heads of some synbranchid eel specimens of the genus Ophisternon are protruded. The most conspicuous, however, is a great number of eyed and pigmented Rhamdia which can be observed swimming throughout the pool. They have been determined as belonging to the species $R$. guatemalensis (Miller, 1984). These fish show a maximum size of about $200 \mathrm{~mm}$ standard length. 


\section{THE PHOTOTACTIC BEHAVIOR}

\section{Cave Crustacea}

Among the cave crustacean species only $P$. oaxacae reddelli shows a light reaction. It is very intense and clearly photonegative. M. villalobosi as well as Potamalpheops stygicola do not seem to have a photopositive or photonegative response.

\section{Epigean and Cave Rhamdia}

The two tested epigean species $R$. guatemalensis and $R$. laticauda as well as the cave-dwelling $R$. reddelli exhibit a significantly photonegative behavior with respect to all three tested light conditions (Fig. 5). There is no correlation between the degree of photonegative response and the used light intensities in any of the tested groups.

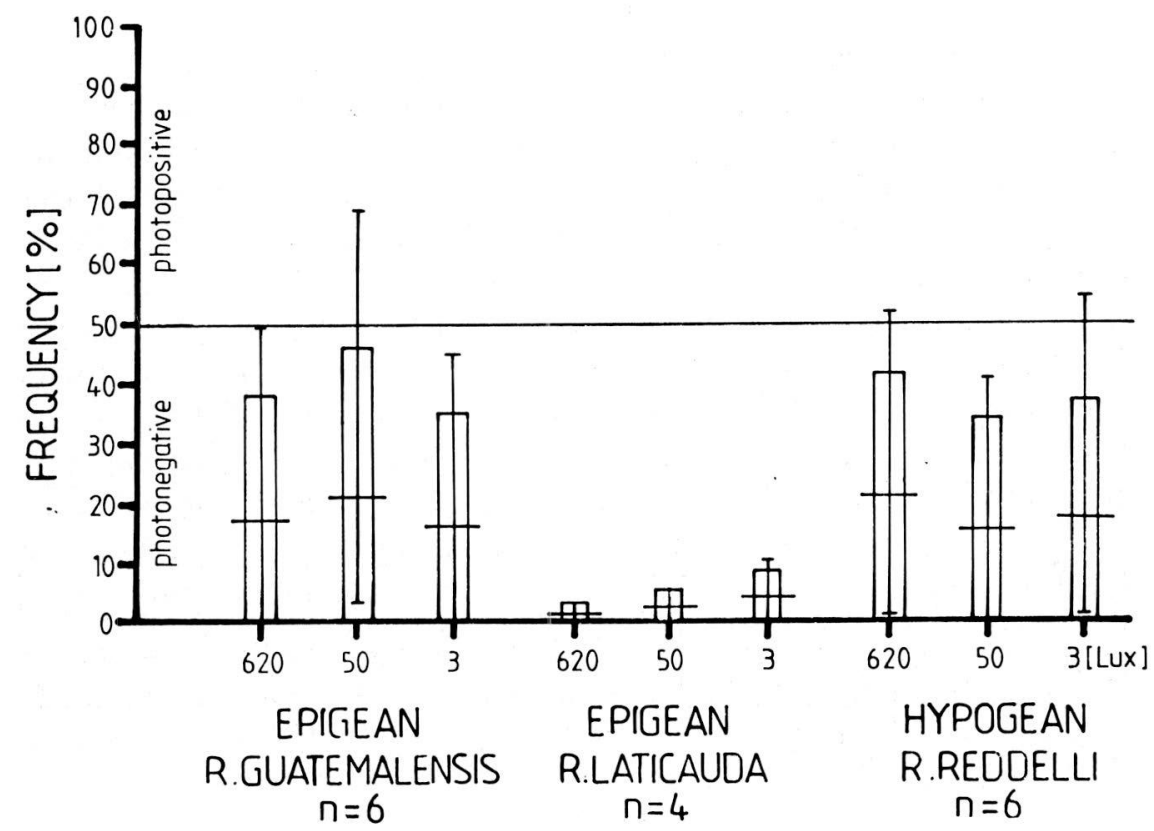

Fig. 5 - Index of light reaction in epigean and cave Rhamdia. 
The photonegative behavior of the epigean $R$. laticauda differs considerably from that of both $R$. guatemalensis and $R$. reddelli. Contrary to these species, $R$. laticauda exhibits an extreme degree and a low variability of scotophilic behavior. Although only a small number of fish were available for the behavioral experiments $(n=6$; 4 ), the photonegative response of the cave fish $R$. reddelli was found to be significantly decreased under high light intensities (620 Lux) compared tô its epigean predecessor $R$. laticauda (MAN-WHITNEY TEST: $\mathrm{p}<0.025)$.

\section{DISCUSSION}

The special hydrographic situation in the San Antonio Cave causes a tremendous fluctuation of living conditions and a periodic large extension of the aquatic environment. During the dry season the aquatic organisms mainly occur concentrated in a small, rapidly streaming creek, whereas during the rainy season they can spread over a slowly-moving enlarged water body.

The most remarkable phenomenon of the San Antonio Cave fauna, however, is its clear cut separation from outside although a continuous connection is provided by the river emerging from the cave. Not a single invading epigean specimen was found in the basin which is close to the cave entrance. This situation is particularly demonstrated by the troglophilic $R$. guatemalensis which is abundant outside the cave. According to Miller (1984), the epigean predecessor to the cave fish $R$. reddelli is $R$. laticauda - a species today obviously not occuring outside the San Antonio Cave. This has no relevance, though, because the closely related $R$. guatemalensis seems to be well adapted for the colonization of caves and is known to be a frequent invader into the underground waters of Yucatan (Hubbs, 1938; Wilkens, 1982). Furthermore, laboratory studies have revealed that specimens from outside the San Antonio Cave can successfully hybridize in the laboratory with the cave $R$. reddelli.

The absence of invading specimens of any epigean species might be due to the fact that the narrow water passages near the cave entrance are populated by specimens of the carnivorous and very aggressive species $R$. reddelli and $P$. oaxacae reddelli. These forms probably concentrate at this place because they have the opportuni- 
ty to feed and prey upon invading specimens. Thus, the absence of any individual of one of the epigean species in the cave could be caused by these aggressive species which form a kind of filter in the entrance region.

Consequently, the location close to the cave entrance is occupied by large and dominating specimens whereas smaller cave fish are found in the more distant regions. In the food poor environment this location is presumably very profitable.

Contrary to the situation today, epigean Rhamdia were probably frequent invaders into the San Antonio Cave system at the beginning of their troglobitic evolution. The results on the phototactic behavior of both $R$. guatemalensis and $R$. laticauda are in accordance with the hypothesis that the initial colonization of caves might be supported by a scotophilic behavior. The extremely scotophilic $R$. laticauda seems to be behaviorally much more adapted to cave life than the related epigean $R$. guatemalensis. The greater dependence of the latter species on visual orientation is not only reflected by its highly variable and rather moderately photonegative behavior but also morphologically by its relatively greater eyes. Thus, it is not surprising that $R$. laticauda founded a series of distinct, troglobitic populations in Mexico whereas $R$. guatemalensis evolved a variety of more or less troglophilic and morphologically slightly different populations in Yucatan (Hubbs, 1938) but obviously no true troglobitic form. In the sense of Howarth (1981), R. guatemalensis may be characterized as a well-adapted troglophilic species which tends to remain an opportunistic exploiter of the cave environment but not to evolve to a troglobite.

The speciation of $R$. reddelli probably began under the conditions of direct genetic contact between epi- and hypogean populations, as has also been described for a cave population of the characin Astyanax fasciatus (Wilkens and Hüppop, 1986). The final separation and speciation of a cave-dwelling population in the San Antonio Cave was certainly not due to factors such as an increased photonegative behavior. Such a segregation mechanism was suggested for the Mexican cave fish Astyanax fasciatus by Breder and Rasquin (1947). The phototactic response of $R$. reddelli, however, is significantly less photonegative than that of its epigean ancestor $R$. laticauda and exhibits a high variability (Fig. 5).

All recent studies on the phototactic behavior of cave fish and 
their epigean relatives gave great evidence against earlier contentions that an increased scotophilia is generally of significance for the speciation of cave fish. A series of investigated cave-dwelling populations of A. fasciatus (Romero, 1985; Langecker, 1989) as well as the Brasilian cave fish Pimelodella kronei (Trajano, 1987) show a greatly reduced photonegative behavior in comparison to their epigean ancestors just as Rhamdia reddelli. Further evidence against such a significance of scotophilia is given by its differential expression during ontogeny. Young specimens of the African cave fish Caecobarbus geertsi and of cave-dwelling A. fasciatus were shown to react almost indifferently to light (Thines, 1958; Romero, 1985). The failing of the photonegative behavior in stages when it proves to be most useful (Thines, 1958) is not in accordance with its suggested function as a separating mechanism.

\section{REFERENCES}

BARR, T.C. Jr. and J.R. HOLSINGER. 1985. Speciation in cave faunas. Ann. Rev. Ecol. Syst. 16: 313-337.

BREDER, C.M. and R. RASQUIN. 1947. Comparative studies in the light sensitivity of blind characins from a series of Mexican caves. Bull. Am. Mus. Nat. Hist. 89: 325-351.

GREENFIELD, D.W., T.A. GREENFIELD, and R.L. WOODS. 1983. A new subspecies of cave-dwelling pimelodid catfish, Rhamdia laticauda typhla, from belize, Central America. Bresenia 19 (20) (1982): 563-576.

HOBBS, H.H. Jr. 1973 a. Three new troglobitic decapod crustaceans from Oaxaca, Mexico. Assoc. Mex. Cave Studies Bull. 5: 25-38.

HOBBS, H.H. Jr. 1973 b. Two new troglobitic shrimps (Decapoda: Alpheidae and Palaemonidae) from Oaxaca, Mexico. Assoc. Mex. Cave Studies Bull. 5: 73-80.

HOWARTH, F.G. 1981. Non-relictual terrestrial troglobites in the tropical Hawaiian caves. p. 539-541. In B. Beck (ed.), Proc. 8th Internat. Cong. Speleol. Nat. Speleol. Soc, Huntsville, Al. HOWARTH, F.G. 1987. The evolution of non-relictual tropical troglobites. Int. J.
Speleol. 16: 1-16.

HUBBS, C.L. 1938. Fishes from the Caves of Yucatan. Carnegie Inst. Wash. Publ. 491: 261-295.

LANGECKER, T.G. 1989. Studies on the light reaction of epigean and cave populations of Astyanax fasciatus (Characidae, Pisces). Mem. Biospel. 16: 169-176.

MILLER, R.R. 1966. Geographical distribution of Central American freshwater fishes. Copeia 1966 (4); 773-802.

MILLER, R.R. 1984. Rhamdia reddelli, new species, the first blind pimelodid catfish from Middle America, with a key to Mexican species. Trans. San Diego Soc. of Nat. Hist. 20 (8): 135-144.

MOSIER, D. 1984. Cave dwelling populations of Rhamdia (Pimelodidae) in Mexico. Assoc. Mex. Cave Studies - Activities Newsletter, Texas, 14: 40-44. REDDELL, J.R. 1981. A review of the cavernicole fauna of Mexico, Guatemala, and
Belize. Texas Mem. Mus. Bull. 27: 1-327.

ROBERTSON, S. 1983 a. Zongolica Project. - 1983. Assoc. Mex. Cave Studies Activities Newsletter, Texas, 13: 36-41. 
ROBERTSON, S. 1983 b. Cueva del Túnel, Veracruz. Assoc. Mex. Cave Studies Activities Newsletter, Texas, 13: 47-49.

ROMERO, A. 1985. Ontogenetic change in phototactic responses of surface and cave populations of Astyanax fasciatus (Pisces: Characidae). Copeia 1985 (4): 10041011.

ROUCH, R. et D.L. DANIELOPOL. 1987. L'origine de la faune aquatique souterraine, entre le paradigme du refuge et le modèle de la colonisation active. Stygologia 3 (4): 345-372.

THINES, G. 1958. Beobachtungen über die Phototaxis und die Thermotaxis des blinden Höhlenfisches Caecobarbus geertsi Blgr. (Cyprinidae). Experienta 14: 381 .

TRAJANO, E. 1987. Biologia do bagre cavernícola, Pimelodella kronei, e de seu provavel ancestral, Pimelodella transitoria (Siluriformes, Pimelodidae). Pd. D. Thesis, University of Sao Paulo.

VANDEL, A. 1964. Biospéologie. La Biologie des Animaux Cavernicoles. GauthierVillars Editeur, Paris.

WILKENS, H. 1982. Regressive evolution and phylogenetic age: The history of colonization of freshwaters of Yucatan by fish and crustacea. Assoc. Mex. Cave Studies Bull. 8: 237-243.

WILKENS, H. 1986. The tempo of regressive evolution: Studies of the eye reduction in stygobiont fishes and decapod crustaceans of the Gulf Coast and West Atlantic region. Stygologia 2: 130-143.

WILKENS, H. and K. HÜPPOP. 1986. Sympatric speciation in cave fish? Studies on a mixed population of epi- and hypogean Astyanax (Characidae, Pisces). Z. zool. Syst. Evol.-forsch. 24: 223-230. 